\title{
Teaching russian as a foreign language in the modern educational paradigm: training dictionaries
}

\author{
Liudmila Alexandrovna Iniutina $^{1^{*}}$, and Tatiana Sergeevna Shilnikova ${ }^{1}$ \\ ${ }^{1}$ Department of the Russian Language; Novosibirsk State Technical University; 20, K. Marx Prospect, \\ Novosibirsk, 630073, Russia
}

\begin{abstract}
The work is devoted to the problem of intensification of teaching Russian as a foreign language in the process of formation and development of the lexical competence of students. The role of educational dictionaries of various types is emphasized. The Experimental Electronic Multilingual Dictionary of Military Terms is presented. It is based on ABBYY Lingvo software for teaching Russian to foreign students of military universities. His vocabulary includes a special vocabulary describing various segments of military activity (weapons, equipment, commands, military life, etc.). For each word there are translations into European languages (boi - English battle, combat; French combat (m); Portuguese combate) and Asian languages (Laos हீ); Arabic معركة; Pashto (د مبارزي. The potential of an electronic multilingual dictionary in the implementation of multicultural and professionally oriented teaching of Russian as a foreign language in a non-linguistic university is identified. The role of the electronic translated multilingual thesaurus in the formation of speech professional competence, which ensures the removal of language barriers in the study of military-technical sciences by foreigners, is determined. The universality of the dictionary is characterized. It was created taking into account those national languages whose speakers receive special education in Russian military universities, and provides opportunities for the redistribution of classroom and independent work of students. Its effectiveness has been proven as a tool for modern interactive, multilingual and multicultural education.
\end{abstract}

\section{Introduction}

The change in the paradigm of education in the context of the processes of globalization and integration of social systems around the world, which is currently taking place, can be defined as communicative and intercultural. Its key pedagogical positions are ideas:

- replacing authoritarian communications with parity ones, involving cooperation in achieving learning goals (pedagogy based on respect for the personality of the learners, their partnership with the teacher [9];

* Corresponding author: 1judina@yandex.ru 
- creation of a unified educational space that promotes training and education of a new type of specialist $[14,17,18,4,21]$.

Modern society makes special demands on the level of cultural and communicative competence of a specialist, his ability to overcome communication barriers. The quality of education today is largely determined by the stable internal motivation of the student, his ability to quickly adapt, the constant renewal of meaningful dialogue with the surrounding society, the development of interpersonal relations in an intercultural environment, the effective achievement of the set goals [13, 15, 23].

According to scientists Grenfell, Hargie and Dickson, Macaro, Gallo and Kuprin [8, 10, $17,7]$ and others, these provisions of the modern paradigm of education are relevant in the process of teaching Russian as a foreign language (RFL). At the forums of the International Association of Teachers of Russian Language and Literature (MAPRYAL) in 2017-2020, the following problems of multicultural education were named as significant:

1) nationally and professionally oriented teaching of RFL;

2) the use of scientific and information technologies in teaching RFL;

3) the all-round promotion of education in Russian, including higher professional, to countries that have not yet entered the circle of those states with which there are already contacts, time-tested (countries in sub-Saharan Africa; countries of Southeast Asia: Laos, Myanmar, Cambodia, etc.).

\section{Statement of the problem}

Experience shows that the stage of pre-university training requires special attention, since the importance of this stage in the process of adaptation of foreigners is high. It is "from mastering the Russian language that the process of obtaining Russian education begins" for every foreign student, and "the success of the future educational activities of the future specialist depends on how favorable the passage of this stage will be" [22].

Russian universities independently determine the content of preparatory programs for RFL, depending on the goals and needs. The main task is the implementation of language training, which would contribute to the development of students in the disciplines of their future specialty. The needs are due to the need to educate students from countries that differ significantly in language, mentality, political and social structure. Teachers-Russianists necessarily take into account the peculiarities of the national composition of the students in the group and gain experience in working with them.

\section{Scientific novelty}

The scientific novelty of this work is the proposed ways of implementing intercultural, professionally oriented teaching of RFL in new textbooks, including lexicographic ones, which were created at the Novosibirsk State Technical University and the Novosibirsk Higher Military Command School: Workbook on Russian as a foreign language. Letter. Phonetics. Intonation [3]; Experimental Electronic Multilingual Dictionary of Military Terms [11]; An associative educational dictionary of topographic vocabulary of the Russian language [12].

The following tasks are solved in the work:

- to find out the place of the electronic multilingual dictionary of military terms in the lexicographic tradition of creating multilingual dictionaries;

- describe the Experimental Electronic Multilingual Dictionary of Military Terms; 
- determine the role of the Experimental Electronic Multilingual Dictionary in the formation and development of lexical competence in the context of professional intercultural communication.

\section{Purpose and research methods}

The aim of this work is to determine the potential of using an electronic multilingual dictionary of military terms for the implementation of multicultural and professionally oriented teaching of RFL in a non-linguistic university.

Thanks to the use of computer technologies and the development of modern methods of interactive teaching of foreign languages, a personality-oriented approach is being implemented. It has become critically important in today's difficult epidemiological conditions associated with Covid-19. In our opinion, distance learning of languages, which turned out to be the only possible one in the current situation in the world, revealed the special relevance of the multimedia transformer method. The essence of this method is to use the whole variety of multimedia tools and tools that can be changed by the participants in the learning process and change the learning process depending on the subjective characteristics of the teacher and the learners " [19]. The use of the method involves the preparation of a large number of training materials: text files, glossaries, presentation materials, workbooks, reference materials, etc.

The need for a certain educational vocabulary naturally arises and is realized in the process of teaching an academic discipline. Lexicographic work aimed at the implementation of the plan requires a significant amount of time and proceeds inseparably with the training of students. Let us name those lexicographic techniques, the use of which in the creation of the Experimental Electronic Multilingual Dictionary is due to the specifics of a military university.

1) Formation of a vocabulary with the help of consultants - teachers of special military disciplines.

2) Linguistic experiment on the translation of special military terms from Russian into their native language by foreign students of 1-5 courses;

3) Dictionary verification.

The use of these methods allows expanding the creative team of authors of the future dictionary, including participation in its creation by foreign students of different courses. As future users of the dictionary, they are involved in the work on clarifying the volume of the dictionary, adjusting the content of dictionary entries, and determining the way of presenting information in an accessible form.

\section{About the lexicographic tradition of creating multilingual dictionaries}

When studying foreign languages, an important role is played by the process of formation and development of lexical competence, which includes knowledge of the vocabulary of the language and the ability to use it in the process of communication. To achieve this goal, a variety of means are used: dictionaries, an explanation of the teacher or students who speak Russian, context, illustrative material. The dictionary is one of the main tools that provide objective information about the lexical meanings of a word, its lexical compatibility/

In the science of language, there is still no generally accepted typology of dictionaries, although attempts to create one have been undertaken by many linguists, in particular L.V. Shcherba, P.N. Denisov, and others [5, 20]. 
We are interested in translation dictionaries - not only bilingual, but multilingual. A good translation dictionary should include stylistic notes and make special mention of cases where the translating equivalent is stylistically imprecise. Translation of words always presents great difficulty, since the volume of the meaning of a word in different languages often does not coincide, figurative meanings in each language develop in its own way. Multilingual dictionaries include the "Dictionary in seven languages (French-GermanEnglish-Italian-Spanish-Portuguese-Dutch-Russian)" compiled by A. and V. Popov, published in 1902 [2].

Of particular importance are multilingual special dictionaries, which provide translation of any industry terminology into a number of languages, for example, the Pocket RussianEnglish-French-Italian-Danish and Norwegian-Latvian marine dictionary published in Russia in 1881[2]. In this regard, multilingual special dictionaries are a key element in teaching RFL in non-linguistic universities (technical, commercial, economic, agricultural, military, etc.) and can have a different target setting

\section{Description of the Experimental Electronic Multilingual Dictionary of Military Terms}

An experimental electronic multilingual dictionary of military terms based on ABBYY Lingvo software. Its vocabulary includes basic military terms and professionalisms (lexemes / phrases) describing different segments of military activity (weapons, uniforms, military teams, equipment, military life, etc.). When compiling the vocabulary, the basic concepts that are basic in this profession were taken into account. The proposed tables clearly demonstrate the thematic variety of vocabulary in the dictionary we have created.

Table 1. Military terms.

\begin{tabular}{|c|c|c|c|c|}
\hline Русский & English & Français & Portugues & ผาราลาอ \\
\hline автоматчик & automatic rifleman & $\begin{array}{l}\text { tireur à la } \\
\text { mitraillette }\end{array}$ & atirador & ถิบยิวยิน \\
\hline артиллерист & artillery man & artilleur (m) & artilheiro & บึมใช่ยชั่าลิม \\
\hline база & $\begin{array}{l}\text { Military base, military } \\
\text { post }\end{array}$ & base militaire & $\begin{array}{c}\text { base ( } \\
\text { military) }\end{array}$ & ตั้งขับ \\
\hline блокпост & checkpoint & poste de blocage & posto & ทำธс๒รทำบั่ \\
\hline $\begin{array}{c}\text { боевая } \\
\text { машина } \\
\text { пехоты (БМП) } \\
\end{array}$ & infantry combat vehicle & $\begin{array}{l}\text { véhicule de } \\
\text { combat } \\
\text { d'infanterie } \\
\end{array}$ & $\begin{array}{l}\text { carro de } \\
\text { combate } \\
\text { infateiro }\end{array}$ & 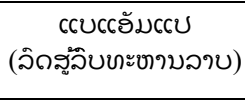 \\
\hline бой & batttle, combat & combat $(\mathrm{m})$ & combate & हึ? \\
\hline $\begin{array}{c}\text { бронетранспо } \\
\text { ртёр (БТР) } \\
\end{array}$ & $\begin{array}{c}\text { armored personnel } \\
\text { carrier }\end{array}$ & véhicule blindé & $\begin{array}{c}\text { carro } \\
\text { blindado }\end{array}$ & ลิถขุ่มตราะ \\
\hline взвод & platoon, troop & $\begin{array}{l}\text { section }(\mathrm{f}) \\
\text { (peloton }(\mathrm{m})\end{array}$ & pelotão & ข्य०० \\
\hline дальность & range, range capability & éloignement (m) & $\begin{array}{c}\text { alcance } \\
\text { (distância) }\end{array}$ & ๑อามไรฐุดโขยล \\
\hline окоп & $\begin{array}{l}\text { emplacement; tank cut; } \\
\text { fighting hole }\end{array}$ & tranchée (f) & trincheira & ?มถง9 \\
\hline разведчик & $\begin{array}{l}\text { intelligence officer; } \\
\text { reconnaissance man; } \\
\text { reconnaissance officer }\end{array}$ & $\begin{array}{c}\text { agent de } \\
\text { renseignement }\end{array}$ & reconhecedor & ริบฉ่าอ \\
\hline ракетчик & $\begin{array}{l}\text { guided missileman; } \\
\text { rocketeer; missileer }\end{array}$ & missilier $(\mathrm{m})$ & $\begin{array}{c}\text { operador de } \\
\text { missil }\end{array}$ & ลูภรงบ \\
\hline связист & $\begin{array}{l}\text { communications man; } \\
\text { signalman, } \\
\text { communicator } \\
\end{array}$ & $\begin{array}{l}\text { agent de } \\
\text { transmission }\end{array}$ & comunicador & ถิบริจาบ \\
\hline устав & $\begin{array}{l}\text { army regulation, } \\
\text { regimen, mandate }\end{array}$ & $\begin{array}{c}\text { statut }(\mathrm{m}) \\
\text { (reglement }(\mathrm{m}))\end{array}$ & $\begin{array}{c}\text { estatuto } \\
\text { (regulamento) }\end{array}$ & ปั้มทิลละบృบ \\
\hline
\end{tabular}


Table 2. Teams.

\begin{tabular}{|c|c|c|c|c|}
\hline Русский & English & Français & Portugues & ๒ๆฐาลาว \\
\hline Вольно! & Stand at ease! & Repos! & $\begin{array}{c}\text { Reposo! } \\
\text { (Descansar) }\end{array}$ & ผัง (ฉิๆ) \\
\hline $\begin{array}{c}\text { Выйти из } \\
\text { строя! }\end{array}$ & $\begin{array}{c}\text { Front and } \\
\text { center! }\end{array}$ & Sortir du Rang! & $\begin{array}{c}\text { Sair da } \\
\text { formatura! }\end{array}$ & ฮงภไบลอมศсฤอ \\
\hline $\begin{array}{l}\text { Занять } \\
\text { место в } \\
\text { строю! }\end{array}$ & $\begin{array}{l}\text { Take a place in } \\
\text { the ranks! }\end{array}$ & $\begin{array}{l}\text { Aligner dans le } \\
\text { rang! (se mettre } \\
\text { en places) }\end{array}$ & $\begin{array}{l}\text { Oucupar lugar } \\
\text { na formatura! }\end{array}$ & บ่มิบฮ่นอ่าวจิยิบลอม \\
\hline К бою! & $\begin{array}{c}\text { In action! On } \\
\text { guard! Contact! } \\
\text { Charge! }\end{array}$ & Au combat! & Ao combate! & भృมยิว \\
\hline $\begin{array}{c}\text { Короче } \\
\text { шаг! }\end{array}$ & Step short! & Demi-pas! & Diminuir-passo! & เอิรบาลร้าอ \\
\hline Кругом! & About turns! & Tournez-vous! & Meia-volta! & ร่าวัวขับ \\
\hline Смирно! & $\begin{array}{l}\text { Room shun! } \\
\text { Attention! }\end{array}$ & $\begin{array}{c}\text { Fixe! (gardez } \\
\text { vous!) }\end{array}$ & Firme! & กิว \\
\hline Становись! & Fall in! & Alignez-vous! & $\begin{array}{l}\text { Levantem-se } \\
\text { (de pe)! }\end{array}$ & จักсcฤอ \\
\hline $\begin{array}{l}\text { Стать в } \\
\text { строй! }\end{array}$ & $\begin{array}{c}\text { Fall in! Fall into } \\
\text { line! }\end{array}$ & Aligne-toi! & $\begin{array}{l}\text { De pe na } \\
\text { formatura! }\end{array}$ & เฉิาธсท้อ \\
\hline Стой! & Stop! Halt! & Stop! (arrête-toi!) & Para! & छ๐! \\
\hline $\begin{array}{c}\text { Шагом - } \\
\text { марш! }\end{array}$ & Forward march! & $\begin{array}{l}\text { Au pas - marche! } \\
\text { (pas de route, } \\
\text { marche!) }\end{array}$ & $\begin{array}{l}\text { Marcar - } \\
\text { Passos! }\end{array}$ & ตั้าลลิบ \\
\hline Шире шаг! & Step out! & A grand pas! & Passos maior! & ธั้มท้าอ \\
\hline
\end{tabular}

Table 3. Social and everyday concepts.

\begin{tabular}{|c|c|c|c|c|}
\hline Русский & English & Français & Portugues & ๒ๆฐาลาว \\
\hline берцы & $\begin{array}{l}\text { combat boots, } \\
\text { ankle boots }\end{array}$ & rangers $(\mathrm{m}, \mathrm{pl})$ & bota militar & เทิบชะขาบ \\
\hline госпиталь & hospital & hôpital (m) & hospital & โธรข่ปชะะขาม \\
\hline казарма & $\begin{array}{c}\text { caserne, military } \\
\text { barrack }\end{array}$ & caserne (f) & kazerna & ขํัตัรบะขาาม \\
\hline $\begin{array}{l}\text { караульное } \\
\text { помещение }\end{array}$ & watch house & poste de garde & posto da Guarda & ลิบยามราวบิม \\
\hline $\begin{array}{l}\text { контрольно- } \\
\text { пропускной } \\
\text { пункт (КПП) }\end{array}$ & checkpoint & poste de contrôle & $\begin{array}{l}\text { posto de } \\
\text { controle }\end{array}$ & บะตูโ2รใช่ย \\
\hline маскхалат & $\begin{array}{l}\text { camouflage } \\
\text { smock }\end{array}$ & $\begin{array}{l}\text { déguisement }(\mathrm{m}) \\
\text { (camouflage }(\mathrm{m}) \text { ) }\end{array}$ & $\begin{array}{l}\text { costume de } \\
\text { camuflagem }\end{array}$ & เริ้อเธ2บภายవิ2าอ \\
\hline нашивки & chevron & chevron $(\mathrm{m})$ & chevron & ภาเลิ่าลิบ \\
\hline $\begin{array}{c}\text { обмундирова- } \\
\text { ние }\end{array}$ & equipment & équipement (m) & equipamentos & 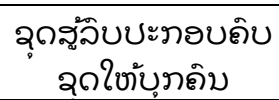 \\
\hline плац & $\begin{array}{l}\text { hardstand; parade } \\
\text { ground; drill } \\
\text { square; square }\end{array}$ & place d'arme & parada & เลิ่บโธวรรม \\
\hline парадная форма & $\begin{array}{l}\text { parade uniform; } \\
\text { full-dress uniform }\end{array}$ & tenues de défilé & $\begin{array}{c}\text { fardamento } \\
\text { Oficial (para } \\
\text { parada) }\end{array}$ & เลิองต่วขทับ \\
\hline полевая форма & $\begin{array}{l}\text { battle dress, } \\
\text { combat dress }\end{array}$ & tenues de brousse & $\begin{array}{c}\text { farda de campo } \\
\text { (campanha) }\end{array}$ & เถึององทระชบาม \\
\hline санчасть & $\begin{array}{c}\text { infirmary, medical } \\
\text { unit }\end{array}$ & $\begin{array}{l}\text { service de santé } \\
\text { (de soins) }\end{array}$ & sanitário & โธวข่ป \\
\hline
\end{tabular}


Each lexical unit has been translated into four languages (English, French, Portuguese and Lao), whose native speakers - foreign students - study in Novosibirsk universities, including a higher military school. A foreign student can start working with the materials of the dictionary in his own language (any of the indicated).

\section{Electronic multilingual dictionary and the formation of speech professional competence in the context of intercultural communication}

Foreign students studying at a higher military school must, in a short time, master a huge layer of vocabulary that can ensure their participation in various spheres of communication: from everyday life to educational and professional. RFL teachers at a military university should take into account that the circle of communication in Russian for a foreign military specialist is much more limited than that of foreigners studying in civilian universities, and the social and everyday aspects of the life of military people have a number of peculiarities (clear social hierarchy, one-man command, rigid daily routine, field trips to practical classes, military uniform with all the attributes, a medical unit and a hospital (not a clinic and a hospital), etc. Therefore, already in the first year of training, students should work with bilingual or multilingual dictionaries covering a large volume vocabulary of the Russian language.

At the first practical lessons in Russian as a foreign language, it is very important to support the formation of pronunciation skills, reading technique of students, especially during the hours of independent training $[3,16]$. At the same time, the teacher acquaints cadets with a presentation containing an illustration demonstrating the meaning of the lexical unit being introduced, spelling with an emphasis, as well as an audio file. For selfpreparation, students can use the presentation materials. Such work takes place in the linguaphone-computer class especially effectively.

With further study of the Russian language, when getting acquainted with abstract vocabulary, the teacher can use the digitized versions of "paper" dictionaries or their versions in PDF format.

Thus, for the formation and development of lexical skills and abilities of foreign military personnel, teachers of the Russian language and teachers of other disciplines can use a variety of information computer technologies. The implementation of the latter can be considered the Experimental Electronic Multilingual Dictionary of Military Terms [11], which is designed to help form speech professional competence, which ensures the removal of language barriers when foreigners study military sciences. The level of effectiveness of such training depends on the characteristics of the presentation of educational information, on the level of development of tools for managing educational and cognitive activities among foreign military personnel [22].

As a rule, the program of the first year of study in RFL does not take into account the need for professional training in a particular specialty. The volume of professional vocabulary is not reflected in the existing lexical minima, but it is a significant in scope and thematically diverse layer of vocabulary. The actual number of classroom lessons in RFL (initial course) does not allow for systematic and regular mastering of special (military) terminology. At the same time, the pre-university training of future officers presupposes the obligatory knowledge of military terminology both at the basic and at the advanced level, otherwise the students face great difficulties in studying special specialized courses.

Note that initial military training and the desire to master the military profession are sufficient motivation for enhanced independent work of foreign cadets [6]. The task of the 
teacher is to organize such independent work. The multilingual "military thesaurus" described above is proposed to be used as a teaching aid. Its structure and content are available for independent work with foreign cadets.

The independent mastery of military terminology by foreign servicemen (with the support and supervision of a teacher) helps to remove possible language barriers in the study of military sciences and in intercultural communication with colleagues. We repeat that students get access to the dictionary in the linguaphone and computer classes.

It should be emphasized that students in military universities cannot access the Internet and use its capabilities (including various "translator" programs) in connection with the requirements of the secrecy regime. Strict observance of these requirements provides for a ban on the use of computers and other devices (including telephones) on the territory of the university with access to the world wide Internet. In such a situation, a multilingual electronic dictionary is a necessary, convenient and in-demand teaching aid both in the classroom with a teacher and in the process of self-study.

\section{Conclusion}

So, the creation of dictionaries of a new type today in the 21 st century is recognized by the linguistic community as one of the most urgent tasks. Educational dictionaries seem to be especially in demand because they play an important role in the educational process.

An experimental electronic multilingual dictionary of military terms helps foreign students to learn Russian to the extent necessary for their professional training. The dictionary is universal, since

1) if necessary, the volume of the vocabulary and the number of target languages can be increased;

2) it can be used in the classroom with a teacher and in the process of self-training, used for intensive immersion in the material, for mastering vocabulary in an individual and comfortable mode for students;

3 ) it is an effective means of redistributing the classroom load in the study of RFL.

The creation of the Experimental Electronic Multilingual Dictionary is, to a certain extent, conditioned by the specifics of a military university. The special value of the dictionary presented in the work as an educational dictionary is seen in the fact that it is a modern electronic tool. It contributes to an increase in the intensification of teaching RFL, since the objective need of our time, society and the individual is interactive, multilingual and multicultural higher education.

\section{References}

1. K.V. Akhramenko. Vliyaniye korporativnoy kul'tury voyennogo vuza na yazykovoye soznaniye kursantov [The influence of the corporate culture of a military university on the linguistic consciousness of cadets], in Mir nauki, kul'tury, obrazovaniya. Seriya Ekologiya. Kul'turologiya. Filologiya. Iskusstvovedeniye. Pedagogika. Psikhologiya [World of science, culture, education. Ecology series. Culturology. Philology. Art criticism. Pedagogy. Psychology]. 3 (28), 204-210 (2011).

2. I.V. Balkanov. Teoriya i praktika voyennoy leksikografii vtoroy poloviny XX veka (na materiale nemetsko-russkogo voyennogo slovarya) [Theory and practice of military lexicography in the second half of the 20th century (based on the German-Russian military dictionary)], in Problemy sovremennogo mira glazami molodezhi sbornik nauchnykh trudov [Problems of the modern world through the eyes of youth, collection of scientific papers], Moscow, 212-217 (2015). 
3. M.V. Barbasoyeva, N.S. Brem, M.K. Chireikin, Yu.Yu. Korotkaya, A.E. Masyuk and A.A. Suchkova. Rabochaya tetrad' po russkomu yazyku kak inostrannomu. Pis'mo. Fonetika. Intonaciya (elelmentarnyi uroven'): uchebnoye posobiye [Workbook on Russian as a foreign language. Letter. Phonetics. Intonation (elementary level)], Novosibirsk, NVVKU, 102 p. (2016).

4. A.P. Beketova. Formirovaniye mezhkul'turnoi tolerantnosti studentov telekommunikacionnykh special'nostei v obrazovatel'nom processe vuza [Formation of intercultural communicative tolerance of students of telecommunication specialties in the educational process of the university]. (PhD dissertation), Ekaterinburg (2018).

5. P.N. Denisov. Ocherki po russkoy leksikologii i uchebnoy leksikografii [Essays on Russian lexicology and educational lexicography]. Moscow, 253 p. (1974).

6. N.V. Fomashina. Organizatsiya samoobrazovaniya budushchikh voyennykh spetsialistov [Organization of self-education of future military specialists], in Izvestiya RGPU im. A.I. Gertsen, 45, 433-466 (2007).

7. Y.A. Gallo, and T.V. Kuprina. Teoreticheskiye I prakticheskiye aspekty obucheniya inostrannym yazykam $\mathrm{v}$ polilingvisticheskom kontexte [Theoretical and practical aspects of teaching foreign languages in a poly-linguistic context], in Y.A. Gallo (Ed.), Obucheniye russkomu yazyku kak inostrannomu: sovremennye tekhnologii prepodavaniya [Teaching Russian as a foreign language: modern teaching technologies], Prešov, Univerzitna knižica Prešovskej Univerzity v Prešove [University Library of Prešov University in Prešov], 15-22 (2010).

8. M. Grenfell and V. Harris. Modern language learning strategies in theory and practice. London, Routledge, 178 p. (1999).

9. R.Z. Hairullin. The specificity of the education process at the university in the multinational group, in Teaching at the university level: Cross-cultural perspectives from the United States and Russia, USA, Charles C. Thomas Publisher, LTD, 127-142 (2007).

10. O. Hargie and D. Dickson. Skilled interpersonal communication. Research, theory and practice. Routledge, London and New York, 542 p. (2004).

11. L.A. Inyutina, E.YU. Kulikova, A.A. Suchkova and T.S. Shilnikova. Experimental'nyi elektronnyi mnogoyazychnyi slovar' voyennykh terminov [Experimental electronic multilingual dictionary of military terms]. Novosibirsk, NVVKU. (2017).

12. L.A. Inyutina and T.S. Shilnikova. Assotsiativnyy uchebnyy slovar' topograficheskoy leksiki russkogo yazyka : uchebnoye posobiye [An associative educational dictionary of topographic vocabulary of the Russian language: a tutorial]. Novosibirsk, Manuskript-SIAM, 52 p. (2019).

13. N.A. Kameneva Rol' sociokul'turnykh I etnolingvisticheskikh aspektov v formirovanii mezhkul'turnoi kompetencii [The role of sociocultural and ethnolinguistic aspects in the formation of intercultural competence], in Informacionnye I kommunikativnye tekhnologii v rusistike: sovremennoye sostoyaniye I perspektiva: III Mezhdunarodnaya virtual'naya nauchno-prakticheskaya konferenciya, 25-28 maya 2010, Yerevan. Sbornik nauchnykh dokladov [Information and communication technologies in Russian: modern state and perspective: III international Virtual scientific-practical conferene, 25-28 may 2010, Yerevan. Collection of scientific reports, Yerevan, Limush, 67-70 (2010).

14. Yu.V. Korneeva. Obucheniye mezhkul'turnoi delovoi kommunikacii na osnove keisovoi metodiki [Teaching intercultural business communication on the basis of a case-study methodology]. (PhD dissertation), Ekaterinburg (2012). 
15. T.V. Kuprina. Osobennosti integracionnogo mul'tilingvizma v sovremennom diskurse [Features of integration multilingualism in modern discourse], in A. Petríková, Y. Gallo (Eds), Prepodavaniye russkogo kak inostrannogo v polikul'turnom prostranstve [Teaching Russian as a foreign language in a multicultural space], Prešov, Univerzitna knižica Prešovskej Univerzity v Prešove [University Library of Prešov University in Prešov], 164-172 (2012).

16. A. Kuznetsov, A. Lamtev, Yu. Lezhenin, A. Zhuikov, M. Maltsev, E. Boitsova, N. Bogach, E. Pyshkin. Cross-Platform Mobile CALL Environment for Pronunciation Teaching and Learning 01005, in The $2^{\text {nd }}$ ACM Chapter International Conference on Educational Technology, Language and Technical Communication (ETLTC2020), 77, (2020). DOI: https://doi.org/10.1051/shsconf/20207701005

17. E. Macaro. Learner Strategies in Foreign and Second Language Classrooms. London, Continuum, 282 p. (2001).

18. R.L. Oxford. Language learner strategies. What every teacher should know. Boston, MA, Heinle \& Heinle Publishers, 342 p. (1990).

19. A. Petrikova, T. Kuprina and Ya. Gallo. Osnovy mezhkul'turnoi didaktiki [Basics of intercultural didactics]. Moskva, Russkii yazyk, 376 p. (2015).

20. L.V. Shcherba. Opyt obshchey teorii leksikografii. Osnovnyye tipy slovarey [Experience of the general theory of lexicography. The main types of dictionaries], in Izv. AN USSR, OLYA, 3, 89-117 (1940).

21. S.G. Terminasova. Yazyk I mezhkul'turnaya kommunikaciya [Language and intercultural communication]. Moscow, Slovo, 163 p. (2000).

22. L.A. Verbickaya. Russkii yazyk kak inostrannyi v sisteme podgotovitel'nykh otdelenii rossiiskikh vuzuv: Sbornik informacionno-analiticheskikh materialov [Russian as a foreign language in the system of preparatory departments of Russian universities: Collection of information and analytical materials]. St. Petersburg, ROPRYAL, 110 p. (2017).

23. K. Vlčkova. Strategies learned in a foreign language [Strategie učeni cizimu jazyku]. (PhD dissertation [Dizertačni prace]). Brno (2005). 